\title{
Optimal management of renewable and fossil fuel energy systems in a smart community
}

\author{
C. Brandoni ${ }^{1}$, A. Arteconi ${ }^{2}$, G. Ciriachi $^{3} \&$ F. Polonara ${ }^{3}$ \\ ${ }^{1}$ University of Ulster at Jordanstown, UK \\ ${ }^{2}$ Università degli studi eCampus, Italy \\ ${ }^{3}$ Università Politecnica delle Marche, Italy
}

\begin{abstract}
The present paper focuses on the energy aspects related to sustainable communities aimed at becoming smart. In particular, the paper discusses optimal strategies for the management of renewable energy systems (RES) and fossil fuel energy systems. Marche Region, one of the 21 Italian administrative divisions, has been taken as a reference case in order to compare different strategies. The area is characterized by a high percentage of electricity imported from the grid, suggesting the importance of increasing the local production to become sustainable. The year 2020 has been taken as the target year. An energy model of the area has been built considering RES potential and energy saving initiatives defined in the Regional Energy Master Plan. The model has been developed with EnergyPLAN, an optimization tool developed by Aalborg University and used to assess energy systems Three different solutions for the integration of RES and the minimization of fossil fuel consumption have been considered: i) a Demand Side Management technique related to the introduction of heat pumps seeking to use the excess of electricity derived from renewable production; ii) the use of micro-CHP systems in buildings to compensate for the variability of RES production; iii) the introduction of EVs with dump and smart charge. The best results come from HPs and EVs with smart charge, which are able to reduce the electricity in excess and minimize the primary energy consumption, in particular when a high share of intermittent renewable is introduced.
\end{abstract}

Keywords: energy planning, renewable energy system, demand side management, heat pumps, electric vehicles, micro-CHP plants. 


\section{Introduction}

A smart community is defined as "a community in which government, business, and residents understand the potential of information technology, and make a conscious decision to use that technology to transform life and work in their region in significant and positive ways" [1].

The present paper focuses on the energy aspects related to smart communities, in particular, on optimal strategies for the management of Renewable Energy Systems (RES) and fossil fuel energy systems in sustainable communities. Optimal algorithms, indeed, must be introduced to control the supply and demand balance, with the aim at minimizing the entire energy consumption.

It is worth noting that researchers and policy makers have recently paid special attention to the role of cities and communities, from which the new energy paradigm takes origin [2]. Such interest has been also developed from the consciousness of the important contribution to GHG emissions coming from cities and the increase in urban population [3-6].

In Europe, it has motivated the launch of important European programs such as the 'Smart Cities and communities' initiative. The challenge, launched in 2011, initially covered only energy aspects; successively it was extended to include the transport and ICT sector with the launch of the European Innovation Partnership for Smart Cities and Communities in July 2012 [7]. Such initiative aims to overcome obstacles to the development of smart cities and communities, to co-fund demonstration projects and to help coordinate existing initiatives and projects.

To better face the challenge of creating a sustainable society, the introduction of distributed generation, in particular renewable generation together with an active demand response is unavoidable.

Renewable systems can be used both for thermal and electricity production, as well as for transports, but some of renewable sources are intermittent and not perfectly predictable, such as for PV and wind production. Consequently a high share of renewable requires the development of a more integrated energy system and high investment on ancillary resources to balance demand and supply at any time. In order to postpone investments in the existing grid, possible optimal strategies are the introduction of: i) micro-grids, which are able to internally compensate the variability coming from fluctuating renewable sources and ii) Demand Side Management, DMS, techniques, aimed at limiting the impact of the electricity in excess, through energy storage and an active response of energy demand. Micro-grids, in addition to renewable devices, can comprise storages, and micro-CHP systems fuelled by natural gas, which are able to compensate fluctuations [8].

The paper, as abovementioned, discusses optimal strategies for the management of energy systems in communities, which want to become smart. Strategies studied are the introduction of: i) micro-generation systems ii) heat pumps coupled to storage systems seeking to use the excess of electricity derived from renewable production and exported to the grid and iii) electric vehicles. 
Marche Region has been taken as case study in order to compare different options. The region is one of the 21 energy divisions that need to fulfil emissions reduction derived by the Italian Burden Sharing. The latter is a mechanism according to which each administrative division must contribute to the EU challenging 2020 climate targets. The year 2020 has been, indeed, taken as reference year.

The renewable capacity installed together with the forecasted energy demand has been derived from the Regional Energy Master Plan, REMP and a recent communication, which has updated regional goals by $2020[9,10]$.

The present work is organised as follows: section 2 discusses the methodology used to build the energy scenario, section 3 focuses on the Marche Region Energy System, section 4 discusses and compares different energy strategies to integrate renewable sources and minimise the overall energy consumption.

\section{EnergyPLAN}

EnergyPLAN, a tool developed by Aalborg University to assess energy systems characterised by a high share of renewable sources, has been used to assess the above-mentioned strategies [11].

It is an optimization tool that can be used to assess energy systems on the basis of a regulation criteria defined by the user. It has been widely applied in literature to assess national, regional or local energy systems and to investigate the effects of introducing specific technology $[12,13]$.

All the energy demanding sectors are taken into account: industry, buildings and transport. An hourly distribution of the energy demand and supply must be defined, since an hourly balance is followed.

Examples of input data are: i) energy supply and demand of industry, buildings and transport sectors, ii) characteristics of the energy conversion devices and iii) installed capacity of renewable sources, RES.

The model provides also the possibility to introduce thermal or electrical storages in order to optimally operate the energy system.

The user needs to define the regulation strategy to be followed, which can be either technical or economic. For the present work the minimization of fuel consumption is followed. Furthermore the model allows the user to specify the regulation approach on the basis of which CHP and Heat Pumps, HP, systems and fluctuating renewable energy sources interact.

The outputs of the tool are energy consumption, $\mathrm{CO}_{2}$ emissions and energy balance necessary to meet the energy demand on the basis of the regulation strategy implemented.

\section{The Marche Region territory}

\subsection{Energy system analysis}

The Marche Region is a small region in central-east Italy characterised by about one million and a half inhabitants. All the data shown in the present paragraph 
comes from the Regional Energy master Plan, REM, discussed in a previous paper written by the authors [9]. The REMP discusses low-carbon measures to be developed in the medium-term for both energy demand and supply, aimed at curbing regional greenhouse-gas emissions and establishes guidelines for governing those initiatives in the region.

Figures 1 and 2 show, respectively, the region's final energy consumption by sector and by commodity from 1988 to 2008. Fossil fuels cover a high percentage of energy consumption derived from a strong tertiarisation of the economy. Transportation and civil sectors are, indeed, the main end-users. Figure 2 shows a decrease in electricity consumption, in particular in industrial energy use, in 2008, due to the economic crisis. Agriculture and fishing, although traditionally relevant sectors for the economic activity of the region, have a marginal role, affecting about the $4 \%$ of total demand.

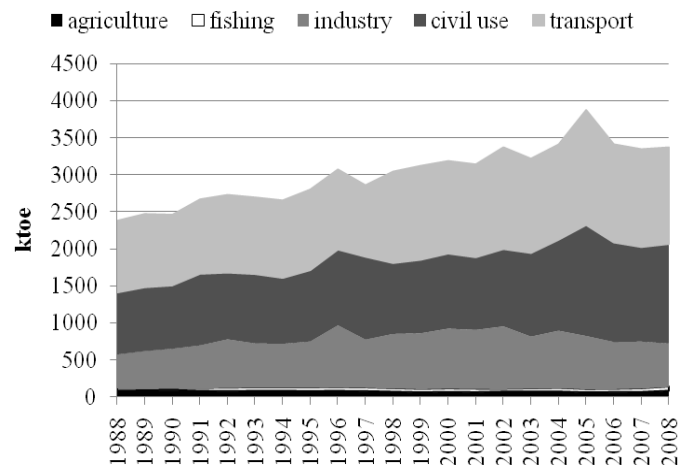

Figure 1: Regional final energy consumption by sector.

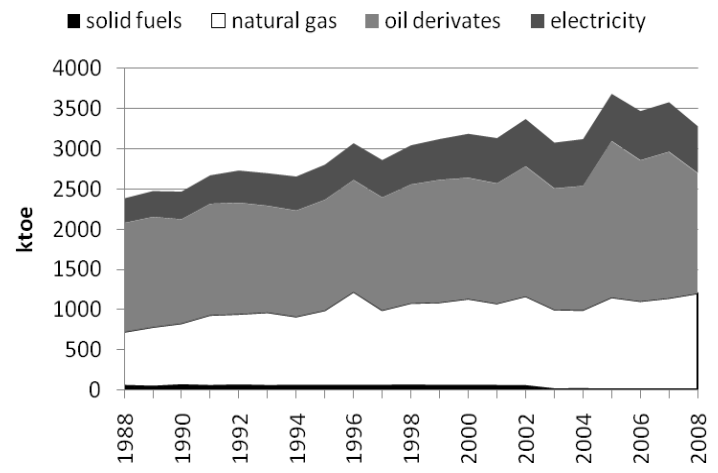

Figure 2: Regional final energy consumption by commodity.

Electricity production and consumption from 1973 to 2012 are shown in Figure 3 . Almost $50 \%$ of electricity demand has been constantly satisfied by imports in the last ten years, although there has been a decrease in electricity 
demand from 2008. This is due to: i) the decrease in electricity production of one of the main thermal power plant of the region and ii) the reduction in the electricity production from the local hydroelectric production. It is worth noting that one of the REMP goals is to reduce this deficit, increasing the local production, in response to national government's recommendation (Law 239/2004 [15]), according to which regions have to look for a balance in their energy demand and supply. Currently, the electricity production from RES covers the $32 \%$ of regional demand. The renewable systems installed are PhotoVoltaic, PV, hydroelectric and biomass plants. No wind farms have been installed yet in Marche Region. Table 1 shows the capacity installed and the corresponding energy production in 2012. PV production is one of the main renewable sources in the territory, thanks to the highly remunerative Italian feed in tariff, which from 2007 has incentivised the widespread of this technology.

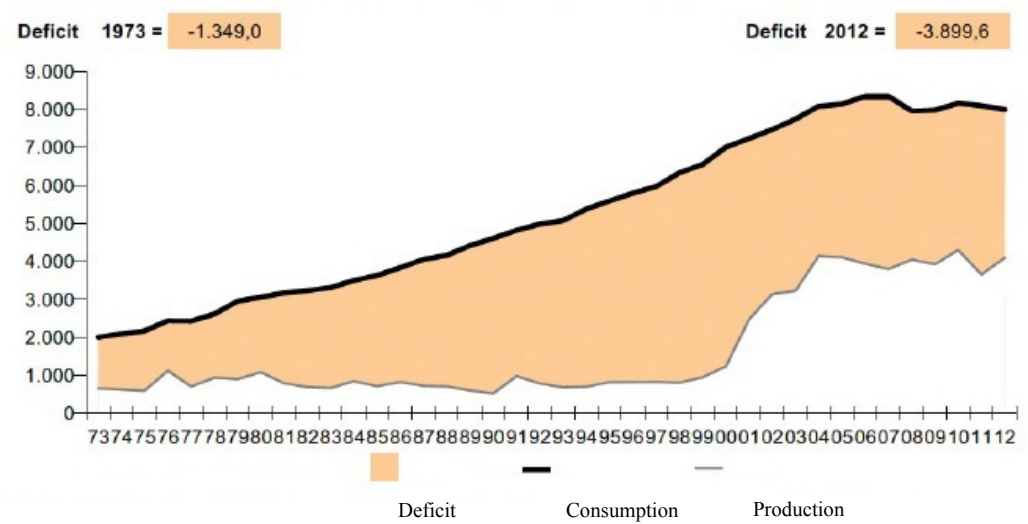

Figure 3: Regional electricity consumption and production [GWh].

Table 1: Renewable production.

\begin{tabular}{|l|c|c|}
\hline & \multicolumn{2}{|c|}{$\mathbf{2 0 1 2}$} \\
\hline \multicolumn{1}{|c|}{ RES-E } & Capacity [MW] & Production [GWh] \\
\hline Hydroelectric & 238.51 & 445.75 \\
\hline Biomass & 24.01 & 102.45 \\
\hline Photovoltaic & 786.59 & 658.38 \\
\hline
\end{tabular}

\subsection{Low-carbon initiatives and their effect on the final demand by $\mathbf{2 0 2 0}$}

Low-carbon measures discussed in the REMP and implemented in the energy model can be classified in three main groups aimed at rationalising demand-side energy use (first category) and improving regional power supply, assessing the introduction of distributed generation and removing the electricity deficit.

Table 2 presents a synoptic diagram of the energy-saving measures analysed together with the assumptions and the parameters used, more widely discussed in 
Table 2: Assumptions and parameters used to assess energy saving measures.

\begin{tabular}{|c|c|c|}
\hline Initiatives & Assumptions & Parameters used \\
\hline \multicolumn{3}{|c|}{ Households: } \\
\hline $\begin{array}{l}\text { High-efficiency } \\
\text { standard for new } \\
\text { buildings }\end{array}$ & $\begin{array}{l}\text { New buildings are the } 0.8 \% \text { of } \\
\text { dwellings }\end{array}$ & 0.004 toe/dwelling \\
\hline $\begin{array}{l}\text { Thermal insulation } \\
\text { in private buildings }\end{array}$ & $\begin{array}{l}100 \mathrm{~m}^{2} \text { apartment } \\
\text { Dwellings built before } 1991\end{array}$ & 0.16 toe/dwelling \\
\hline \multirow{3}{*}{$\begin{array}{l}\text { High-efficiency } \\
\text { household } \\
\text { equipment }\end{array}$} & $\begin{array}{l}110 \% \text { refrigerator per dwellings } \\
41.7 \% \text { high-efficiency refrigerators } \\
\text { installed so far }\end{array}$ & \multirow{3}{*}{0.016 toe/dwelling } \\
\hline & $\begin{array}{l}37 \% \text { washing machines per dwellings } \\
38.9 \% \text { refrigerators installed so far }\end{array}$ & \\
\hline & $\begin{array}{l}100 \% \text { dish machine per dwellings } \\
32.2 \% \text { high-efficiency dish-washing } \\
\text { machine installed }\end{array}$ & \\
\hline High efficiency lamp & $\begin{array}{l}\text { Replacement of } 2 \text { lamps per dwelling } \\
0.0115 \text { toe/light_bulk }\end{array}$ & 0.023 toe $/$ dwelling \\
\hline \multicolumn{3}{|c|}{ Tertiary sector: } \\
\hline $\begin{array}{l}\text { Thermal insulation } \\
\text { in schools }\end{array}$ & $\begin{array}{l}\text { Replacement of single-glazed window } \\
\text { with double-glazed window } \\
\text { Thermal-insulation parameters defined } \\
\text { by Law } 192 / 2005[18] \text { and Decree } \\
311 / 2006,59 / 2009[19,20] \\
\text { Applications of the Best Available } \\
\text { Techniques and materials }\end{array}$ & $\begin{array}{l}30 \% \text { energy reduction } \\
\text { of thermal demand }\end{array}$ \\
\hline \multirow{2}{*}{$\begin{array}{l}\text { High-efficiency } \\
\text { lamp in public } \\
\text { lighting and traffic } \\
\text { lighting }\end{array}$} & $\begin{array}{l}\text { Replacement of } 150 \text { W High-Pressure } \\
\text { Sodium Lamp, HPS, with } 60 \text { W LED } \\
\text { ( } 4000 \text { operation hours) }\end{array}$ & 0.06 toe/year/lamp \\
\hline & $\begin{array}{l}\text { Replacement of } 60 \mathrm{~W} \text { incandescent } \\
\text { light bulk with } 16 \mathrm{~W} \text { LED ( } 4000 \\
\text { operation hours) }\end{array}$ & 0.04 toe/year/lamp \\
\hline \multicolumn{3}{|c|}{ Industry: } \\
\hline $\begin{array}{l}\text { Electricity reduction } \\
\text { in industry } \\
\text { (inverters, high- } \\
\text { efficiency electric } \\
\text { motors, high- } \\
\text { efficiency lamps) } \\
\end{array}$ & $\begin{array}{l}\text { Industry consumption distribution: } 4 \% \\
\text { lightings, } \\
75 \% \text { electric motors, } 21 \% \text { process } \\
\text { Penetration factor for high-efficiency } \\
\text { lighting, high efficiency motors and } \\
\text { inverters, of } 57 \%, 33 \% \text { and } 33 \% \text { [21] }\end{array}$ & $\begin{array}{l}17.8 \% \text { of electricity } \\
\text { consumption }\end{array}$ \\
\hline $\begin{array}{l}\text { Energy production } \\
\text { from biomass }\end{array}$ & $\begin{array}{l}\text { Wood-waste recovery from industry } \\
\text { Modernisation of existing plant to } \\
\text { exploit wood wastes }\end{array}$ & \\
\hline
\end{tabular}


Table 2: Continued.

\begin{tabular}{|l|l|l|}
\hline \multicolumn{1}{|c|}{ Initiatives } & \multicolumn{1}{|c|}{ Assumptions } & Parameters used \\
\hline \multicolumn{2}{|c|}{ Transport: } & \\
\hline & $\begin{array}{l}\text { In application of EU Regulation } \\
443 / 2009 \text { [22], within the 2020 emission } \\
\text { limit of the average car sold to } 130 \mathrm{~g}\end{array}$ & \\
$\begin{array}{l}\text { Promotion of less } \\
\text { polluting cars }\end{array}$ & $\begin{array}{l}\mathrm{CO}_{2} / \mathrm{km} \text { by } 2015 \text { and } 95 \mathrm{~g} \mathrm{CO}_{2} / \mathrm{km} \mathrm{in} \\
2020 .\end{array}$ & \\
\hline $\begin{array}{l}\text { Interventions for } \\
\text { sustainable mobility } \\
\text { and public transport }\end{array}$ & $\begin{array}{l}\text { Reduction of systematic trips home - } \\
\text { work and home - school within the } \\
\text { regional and municipal territory. }\end{array}$ & \\
\hline
\end{tabular}

Table 3: Energy demand by 2020 [ktoe].

\begin{tabular}{|c|c|}
\hline \multirow{2}{*}{$\begin{array}{l}\text { Electricity } \\
\text { Heating }\end{array}$} & 745 \\
\hline & Heating \\
\hline Buildings & 939 \\
\hline Industry & 414 \\
\hline Transport sector & 1,166 \\
\hline
\end{tabular}

previous paper written by some of the authors [14]. Table 3 shows the resulting energy demand, implemented in the 2020 regional energy scenario.

It can be observed that the civil sector and, particularly, the households have many initiatives for the energy-saving measures because, in this sector the regional government has greater decision-making power. In particular, the major contribution derives from thermal-insulation initiatives because most of the buildings in the Marche Region were built before the introduction of important energy-efficiency criteria in the building sectors [16].

Transport is another important sector for energy-savings; the promotion of less polluting cars is an important initiative considered in the model defined on parameters discussed in the Italian Energy Efficiency Plan [17].

\subsection{Renewable sources by 2020}

A main distinction must be done between RES-E, renewable electricity and RES-H, renewable heating. Table 4 shows the RES capacity and corresponding production by 2020 .

As regards RES-E, the increase in hydroelectric production can more likely derive from micro and mini-hydroelectric plants, since there are no areas suitable to install big plants. As discussed in [23] electricity production from biomass can play an important role in Marche Region, with a positive side effect on agriculture sector, thus an interesting contribution can come from this source by 2020. It has been assumed a low increase in PV production, due to the termination of the national supporting scheme. 
As regards wind production, it has been assumed to install a low capacity in the near future, due to non-technical problems (i.e. opposition of Green Movement due to change in rural landscape) that have limited its widespread so far. RES-H are currently less developed RES-E, but in line with the Italian Energy Strategy, they are expected to play a central role in order to reach 2020 EU climate targets. RES-H sources comprise biomass and solar heating.

Table 4: RES capacity and production by 2020.

\begin{tabular}{|l|r|}
\hline & Capacity [MW] \\
\hline PhotoVoltaic & 1,218 \\
\hline River Hydro & 152 \\
\hline Wind & 175 \\
\hline Biomass & 45 \\
\hline Solar heating & 2 \\
\hline
\end{tabular}

\subsection{Simulation results of the 2020 regional energy scenario}

Table 5 shows the energy scenario resulting from the 2020 scenario implemented. It can be seen that thanks to the introduction of a high share of renewable energy there is a reduction in the electricity import with respect to 2012.

Furthermore during summer, part of the electricity produced by PV needs to be exported, since it is not contemporary to the energy demand.

Table 5: 2020 reference scenario.

\begin{tabular}{|c|c|c|}
\hline & $\begin{array}{l}\text { Internal } \\
\text { production }\end{array}$ & Import \\
\hline Coal [TWh/y] & 1.18 & 1.67 \\
\hline Oil [TWh/y] & 13.12 & 0.85 \\
\hline $\mathrm{NG}[\mathrm{TWh} / \mathrm{y}]$ & 17.83 & 4.06 \\
\hline Biomass [TWh/y] & 3.26 & 0.31 \\
\hline \multicolumn{3}{|l|}{ Other RES [TWh/y] } \\
\hline Total [TWh/y] & 38.10 & 6.89 \\
\hline $\mathrm{CO}_{2}$ Emissions [Mtoe] ${ }^{*}$ & \multicolumn{2}{|r|}{7.57} \\
\hline Electricity imported [TWh/y] & \multicolumn{2}{|r|}{3.22} \\
\hline Electricity exported [TWh/y] & \multicolumn{2}{|r|}{0.06} \\
\hline RES share on primary energy [\%] & \multicolumn{2}{|r|}{15.6} \\
\hline RES share on electricity demand [\%] & \multicolumn{2}{|r|}{33.6} \\
\hline Electricity from RES [TWh/y] & \multicolumn{2}{|r|}{2.7} \\
\hline
\end{tabular}

*Excluding $\mathrm{CO}_{2}$ emissions derived from import

For example, Figure 4 shows a day in July, when part of the electricity produced by RES needs to be exported. In order to avoid this problem it is necessary to reduce the "electricity in excess", defined as the electricity produced 
by RES which is not directly used by the local community and therefore fed to the general grid. Furthermore the introduction of a high share of renewable creates grid stability problems. The following paragraph deals with optimal strategies to avoid the above-mentioned concerns.

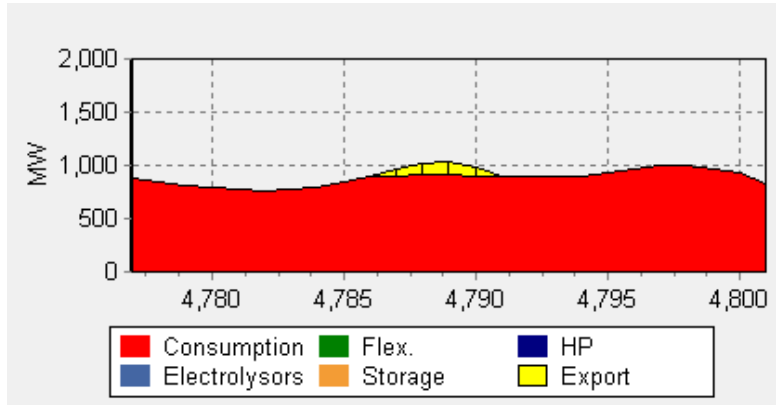

Figure 4: Electricity consumption and export in a day of July [GWh].

\section{Optimal energy strategies}

As previously introduced, the present paragraph investigates optimal management strategies that allow the local grid to act as Smart Grid without heavy investments to adapt the general grid for the introduction of a high share of renewable sources.

Three solutions for better integrate renewable have been considered: i) the introduction of DSM techniques related to the introduction of heat pumps to satisfy the heat demand of buildings, iii) the use of micro-CHP systems in the building sector and ii) the introduction of EVs. As regards the regulation strategy in EnergyPLAN model, a technical optimization aimed at reducing the fuel consumption balancing both thermal and electricity demand has been followed.

In the present study heat pumps are used to satisfy the heat demand in the building sector, seeking to use the excess of electricity derived from renewable production and exported to the grid. It is assumed to cover $3 \mathrm{GWh}$ of heating demand in buildings that corresponds to the $28 \%$, which is a reasonable value.

Table 6 shows the main results. HPs provide a decrease in fuel consumption, consequently in $\mathrm{CO}_{2}$ emissions, the electricity import increases and there is a slight decrease in the electricity excess produced by RES and exported to the grid. This is due to the fact that the main excess coming from RES derives from PV production and it mainly occurs in summer period, while it has been assumed to use heat pumps only for thermal demand. In order to reduce such export, HPs should be applied to satisfy also the cooling needs. The introduction of microCHP, as expected, provides a reduction in import, thanks to the electricity internally produced. The local fuel consumption increases due to the need of natural gas for feeding such systems, but the overall $\mathrm{CO}_{2}$ emissions decreases since energy needs are satisfied in a more efficient way. As regards Electric Vehicles (EVs), it has been assumed to completely replace vehicles fuelled by 
petrol. Two charging typologies have been chosen: i) dump charge and ii) smart charge. In the 'dump charge' the user defines the time for recharging vehicles (a constant recharge from 10 p.m to 7 a.m. has been assumed) and the electricity demand is summed to the electricity demand of the area. In case of 'smart charge', EVs are used to store the electricity produced by intermittent renewable sources and reduce the excess of electricity exported to the grid. The excess of the electricity, as shown in Table 6, consequently decreases. The introduction of EVs increase the import and reduce the overall $\mathrm{CO}_{2}$ emissions.

Table 6: $\quad$ Results derived from different strategies.

\begin{tabular}{|l|c|c|c|c|c|}
\hline & $\begin{array}{c}\text { Fuel } \\
\text { consumption } \\
\text { excl RES } \\
{[\mathrm{TWh} / \mathrm{y}]}\end{array}$ & $\begin{array}{c}\mathrm{CO}_{2} \text { without } \\
\text { import } \\
{[\mathrm{Mton} / \mathrm{y}]}\end{array}$ & $\begin{array}{c}\mathrm{CO}_{2} \text { with } \\
\text { import } \\
{[\mathrm{Mton} / \mathrm{y}]}\end{array}$ & $\begin{array}{c}\text { Electricity } \\
\text { excess } \\
{[\mathrm{TWh} / \mathrm{y}]}\end{array}$ & $\begin{array}{c}\text { Import } \\
{[\mathrm{TWh} / \mathrm{y}]}\end{array}$ \\
\hline BAU & 38.10 & 7.57 & 9.27 & 0.06 & 3.22 \\
\hline HPs & 34.88 & 6.94 & 9.13 & 0.05 & 4.19 \\
\hline Micro-CHP & 39.00 & 7.74 & 8.85 & 0.06 & 2.06 \\
\hline EV dump charge & 35.30 & 6.83 & 8.94 & 0.06 & 4.02 \\
\hline EV smart charge & 35.20 & 6.81 & 8.94 & 0.01 & 4.02 \\
\hline
\end{tabular}

In the 2020 scenario analysed, Marche Region continues to import electricity, suggesting the possibility to increase local generation. In order to appreciate the effect of the solutions studied, when the RES production from intermittent sources increases, Figure 5 and 6 show the effects of the strategies proposed on fuel consumption excluding RES. In case of a high PV and wind production the best results come from HPs and EVs with a smart charge.

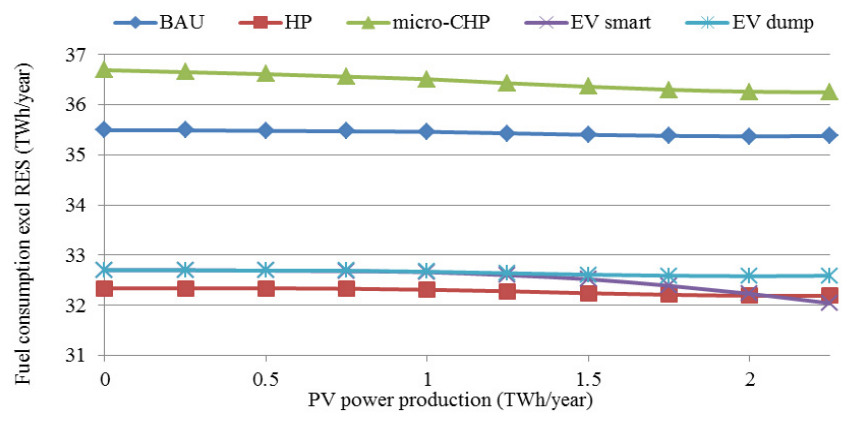

Figure 5: Fuel consumption excluded RES at different PV power production. 


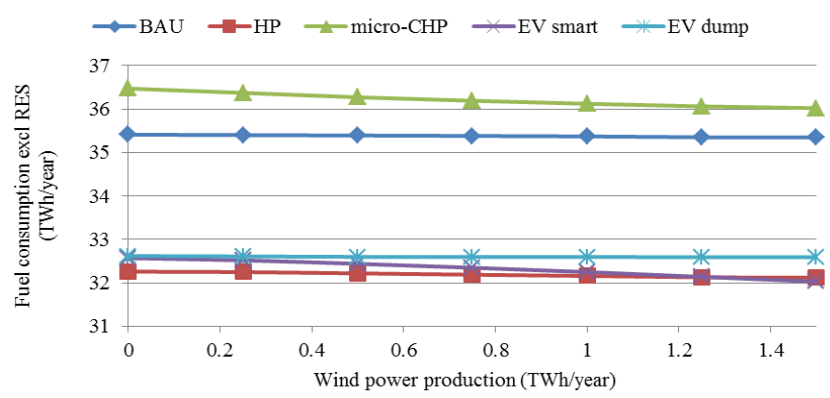

Figure 6: Fuel consumption excluded RES at different wind power production.

\section{Conclusions}

Taking as reference case a sustainable community that aims to become smart, different optimization strategies for integrating a high share of renewable intermittent sources have been studied. Since the area analysed imports a high quantity of electricity, the introduction of a high share of RES-E could help to make the area sustainable. Optimally managing the energy system characterised by a high share of RES provides a reduction in the overall fuel consumption and $\mathrm{CO}_{2}$ emissions. The best strategies appear to be the introduction of HPs, to be used for satisfying both thermal and cooling needs, together with the introduction of EVs with a smart charge.

\section{Acknowledgement}

This project is funded by the European Union under the Marie Curie Action's IRSES (POREEN).

\section{References}

[1] Eger J., The smart communities guide book, 26 November 2001.

[2] Yamagata, Y., Seya, H., Simulating a future smart city: An integrated land use-energy model. Applied Energy, 112, 1466-1474, 2013.

[3] Hiremath, R.B., Shika, S., Ravindranath, N.H., Decentralized energy planning; modelling and application-a review, Renewable \& Sustainable Energy Reviews, 11, 729-752, 2007

[4] Brandoni, C., Polonara, F., Technical and economic aspects of municipal energy planning, International journal of sustainable development and planning, 7(2), 221-236, 2012

[5] Arteconi, A., Brandoni, C., Bartolini, C.M., Polonara, F., Assessment of the impact of local energy policies in reducing greenhouse gas emission, In: Aravossis K, Brebbia CA, editors. Environmental economics \& investment assessment. WIT Press; 2010.

[6] Comodi, G., Cioccolanti, L., Polonara, F., Brandoni, C., Local authorities in the context of energy and climate policy, Energy policy, 51, 737-748, 2012. 
[7] European Innovation Partnership for Smart Cities and Communities in July 2012, Available online (27/1/2014) http://ec.europa.eu/information society/activities/sustainable_growth/cities/index_en.htm

[8] Brandoni, C., Renzi, M., Caresana, F., Polonara, F., Simulation of hybrid renewable microgeneration systems for variable electricity prices. Applied Thermal Engineering, in press, doi: 10.1016/j.applthermaleng.2013.10.044

[9] Regional Energy Master Plan, REMP, Available online (27/1/2014) http://www.ambiente.marche.it/Energia/PianoEnergeticoAmbientaleRegion ale.aspx

[10] Polonara, F., Personal communication, 10/1/2014, Head of the Department of Industrial Engineer and Mathematical Science, Università Politecnica Marche

[11] Lund, H., EnergyPLAN, version 10.0(2012). Department of Development and Planning, Aalborg University; 2012.

[12] Lund, H., Large-scale integration of optimal combinations of PV, wind and wave power into the electricity supply. Renewable Energy, 31(4), 503-515, 2006.

[13] Ćosić, B., Krajačić, G., Duić, N., A 100\% renewable energy system in the year 2050: The case of Macedonia. Energy, 48(1), 80-87, 2012.

[14] Brandoni, C., Polonara, F., The role of municipal energy planning in the regional energy-planning process. Energy, 48, 323-338, 2012

[15] Law 239/2004, "Riordino del settore energetico, nonche' delega al Governo per il riassetto delle disposizioni vigenti in materia di energia".

[16] Law 10/1991, "Norme per l'attuazione del Piano energetico nazionale in materia di uso razionale dell'energia, di risparmio energetico e di sviluppo delle fonti rinnovabili di energia".

[17] Italian Government, Piano d'azione per l'efficienza energetica, 2011,

[18] Italian legislative Decree 192/2005, "Attuazione della direttiva 2002/91/CE relativa al rendimento energetico nell'edilizia".

[19] Italian legislative Decree 311/2006. "Disposizioni correttive ed integrative al decreto legislativo 19 agosto 2005, n. 192, recante attuazione della direttiva 2002/91/CE, relativa al rendimento energetico nell'edilizia".

[20] Italian Presidential Decree 59/2009, Decreto del presidente della Repubblica 59/2009. Regolamento di attuazione dell'articolo 4, comma 1, lettere a) and b), del decreto 19 agosto 2005, n.192, concernente attuazione della direttiva 2002/91/CE sul rendimento energetico in edilizia.

[21] Italian manufacturing and service companies' organization. Proposals for Italy's extraordinary plan for energy efficiency and energy saving, National report, 2009.

[22] EU Regulation, 443/2009, Italian manufacturing and service companies' organization. Proposals for Italy's extraordinary plan for energy efficiency and energy saving, National report, 2009.

[23] Brandoni, C. Di Nicola, G., Polonara, F., Development of renewable energy strategies for small urban areas, in: C.A. Brebbia, T-S Chon eds, Environmental impact 2012; WIT Transactions on Ecology and the Environment, 2012, 265-277. 